\title{
VARIABILITY OF MALONDIALDEHYDE CONTENT AND YIELD ELEMENTS IN Triticum aestivum $L$. UNDER HEAT STRESS CONDITIONS
}

\author{
Stefan Marković*, Marija Petrović, Nevena DJukić \\ University of Kragujevac, Faculty of Science, Department of Biology and Ecology, \\ Radoja Domanovića 12, 34000 Kragujevac, Serbia \\ *Corresponding author; E-mail: stefan.markovic@pmf.kg.ac.rs
}

(Received May 15, 2020; Accepted June 06, 2020)

\begin{abstract}
Heat stress has a significant effect on the growth and development of cereals and affects cereals production by reducing the total yield. High temperatures in plants lead to oxidative stress, which creates reactive oxygen species that are specific to cause damage to the cell membrane. Due to the action of reactive oxygen species, lipid peroxidation can occur. For that reason, it is important to find cultivars that are more resistant to the harmful effects of heat stress and thus enable higher productivity. The aim of this study was to determine the effect of heat stress on the degree of lipid peroxidation and yield elements in leaves of 10 wheat cultivars, in order to select cultivars more resistant to heat stress. The degree of lipid peroxidation was determined spectrophotometrically by measuring the concentration of reactive substances of thiobarbiturate acid (mainly malondialdehyde - MDA). The cultivar Renesansa with the largest increase in MDA in conditions of high air temperature $(2.848 \mu \mathrm{mol} / \mathrm{g} \mathrm{fw})$ was also characterized by the lowest yield (2870 kg/ha). On the other hand, the cultivar Talas with the smallest increase in MDA content $(1800 \mu \mathrm{mol} / \mathrm{g} \mathrm{fw})$ in conditions of high air temperature showed significantly higher yield $(3830 \mathrm{~kg} / \mathrm{ha})$. In this paper was shown that lipid peroxidation has a significant effect on yield reduction in the investigated wheat cultivars. Cultivars Talas, Apač, Hyfi, Mila and Salasar were characterized as cultivars more resistant to heat stress with higher yields. These results suggest that wheat cultivars were significantly different in their ability to respond to heat stress, which could be useful for the development of tolerant wheat cultivars in the breeding programs.
\end{abstract}

Key words: wheat, heat stress, MDA, lipid peroxidation, yield.

\section{INTRODUCTION}

Cereals are an important economic and food resource that's the one of the most important nutrition in the daily human diet (FAROOQ et al., 2011). Abiotic factors are the dominant stress source in higher plants (KHAMSSI et al., 2011) and affect the amount of all cereals produced, which could create food supply problems in the future (CIAIS et al., 2005; BARNABÁS et al., 2008). Due to global warming, heat stress is becoming one of the most 
alarming factors (MAHLA et al., 2012). Heat stress has a significant effect on the growth and development of cereals (PORTER and GAWITH, 1999) and affects wheat production, causing a reduction in yield of up to $71 \%$ (MUSTAFA et al., 2013). Maintaining high yields despite the harmful effects of the environment is an increasing challenge for modern agriculture (GILL and TUTEJA, 2010). Heat stress has a negative effect on plant growth, metabolism and plant cell function (ANDERSON and SONALI, 2004). Physiological damage during heat stress occurs at all levels of structural organization and is mostly dominant at the molecular level (KARUPPANAPANDIAN et al., 2011). Temperatures above $35{ }^{\circ} \mathrm{C}$ reduce the activity of enzymes and significantly limit the processes of photosynthesis (GRIFFIN et al., 2004). High temperatures in plants lead to oxidative stress creating reactive oxygen species (ROS) (SUZUKI and MITTLER, 2006). It is specific for reactive oxygen species to cause damage to the cell membrane (KUMAR et al., 2012), which can result in cell death and plant damage (LIU and HUANG, 2000; MARCUM, 1998). Under oxidative stress, the increased concentration of formed ROS leads to lipid peroxidation causing damage to the cell membrane (BREUSEGEM et al., 2001; AMIRJANI, 2012). Lipid peroxidation is the best indicator of stress and membrane damage (TAULAVUORI et al., 2001) and is accompanied by an increased concentration of malondialdehyde (MDA) (VACCA et al., 2004). Fortunately, plants have evolved mechanisms to remove ROS under stress (ALSCHER et al., 2002). When the ambient temperature is $5{ }^{\circ} \mathrm{C}$ higher than the optimal, the activation of a characteristic set of cellular and biochemical processes necessary for the survival of plants under conditions of heat stress occurs (GUY, 1999). Accumulation of specific heat stress proteins (DJUKIĆ et al., 2019) as well as proline accumulation proved to be one of the adaptation factors to heat stress in wheat (KAVI KISHOR et al., 2005). Stress resistance can differ significantly between wheat cultivars and different adaptation mechanisms can be activated among them.

The development of heat-tolerant cereals, based on the specific cultivar characteristics, can be a promising approach that can meet food needs. By applying biotechnology in cereal breeding, cultivars more resistant to high temperatures can be developed, i.e. cultivars that will give higher yields. In order to advance in this area, it is necessary to identify the damage that can occur due to the high temperatures, the protective mechanisms of cereals from heat stress and the range of genetic variability for the aforementioned mechanisms (FU and HUANG, 2001).

The aim of this study was to determine the effect of heat stress on the degree of lipid peroxidation by measuring malondialdehyde content in the leaves of 10 wheat cultivars, to determine the yield of tested wheat cultivars and to compare them in order to select cultivars more resistant to heat stress.

\section{MATERIAL AND METHODS}

\section{Plant material and field conditions}

In our experiment were used 10 wheat cultivars (Carica, Futura, Renesansa, Ratarica, Vlajna, Mila, Apač, Salasar and Hyfi). The cultivars were sown in the experimental field of the Agricultural Station in Kraljevo $\left(43^{\circ} 47^{\prime} 23.2^{\prime \prime N} 20^{\circ} 32^{\prime} 04.6^{\prime \prime E}\right)$ on meadow-valley black soil. Sowing was done at the end of October 2017. Before sowing, mineral fertilizer (NPP $15: 15: 15)$ was applied in accordance with the recommendations, based on the chemical properties of the soil and the available content of nitrogen, phosphorus and potassium. Samples used for analysis were collected from the experimental field in the middle of the day (11-12 h) in June 2018. Samples were collected on days with a moderate air temperature of 26 ${ }^{\circ} \mathrm{C}$ (samples were collected after a few days with temperatures below $27^{\circ} \mathrm{C}$ ), and after a few days in conditions of high air temperature of 35.4 (samples were collected after a few days 
with temperatures higher than $30{ }^{\circ} \mathrm{C}$ ). The time interval of leaf collection between moderate and high air temperatures was 6-8 days. Sampling of the material was performed in the phenological phase of milk ripening of cereals. Flag leaves of selected cereal cultivars were used for the analysis.

\section{Weather conditions}

Weather conditions during the vegetation season are shown in Figures 1 and 2. During 2018, the average value of air temperature was $12.7^{\circ} \mathrm{C}$ (Fig. 1). Precipitation during the season was $986.9 \mathrm{~mm}$ (Fig. 2). During the milk ripening phase of the cereals when the samples were collected, the average air temperature was $19.9{ }^{\circ} \mathrm{C}$. During the milk ripening phase of the cereals according to period of 5 years, there are 9-10 days with average day temperatures above $30{ }^{\circ} \mathrm{C}$. In days with average day temperatures above $30{ }^{\circ} \mathrm{C}$, maximum temperatures are in the middle of the day (11-12h). Maximum temperatures in June (when samples were collected) according to period of 5 years ranged from $31.2{ }^{\circ} \mathrm{C}$ to $37^{\circ} \mathrm{C}$. According to period of 10 years, year 2018 was the hottest year (Republic hydrometeorological service of Serbia).

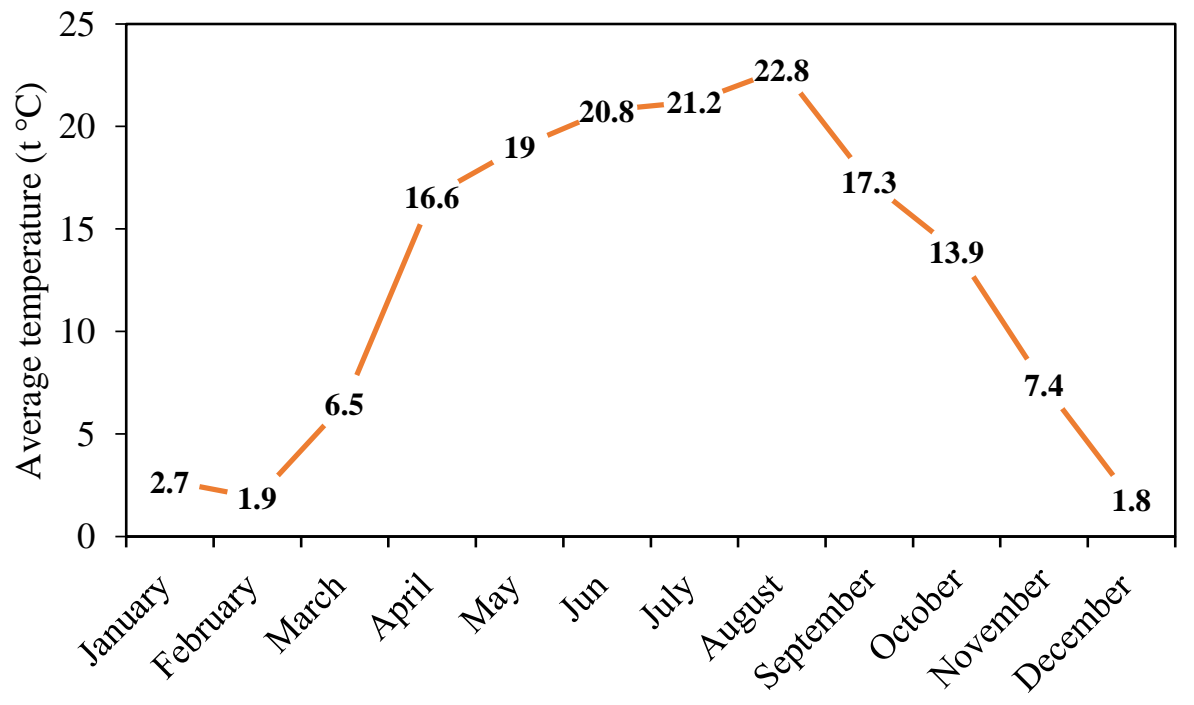

Figure 1. Average values of air temperature shown by months during 2018.

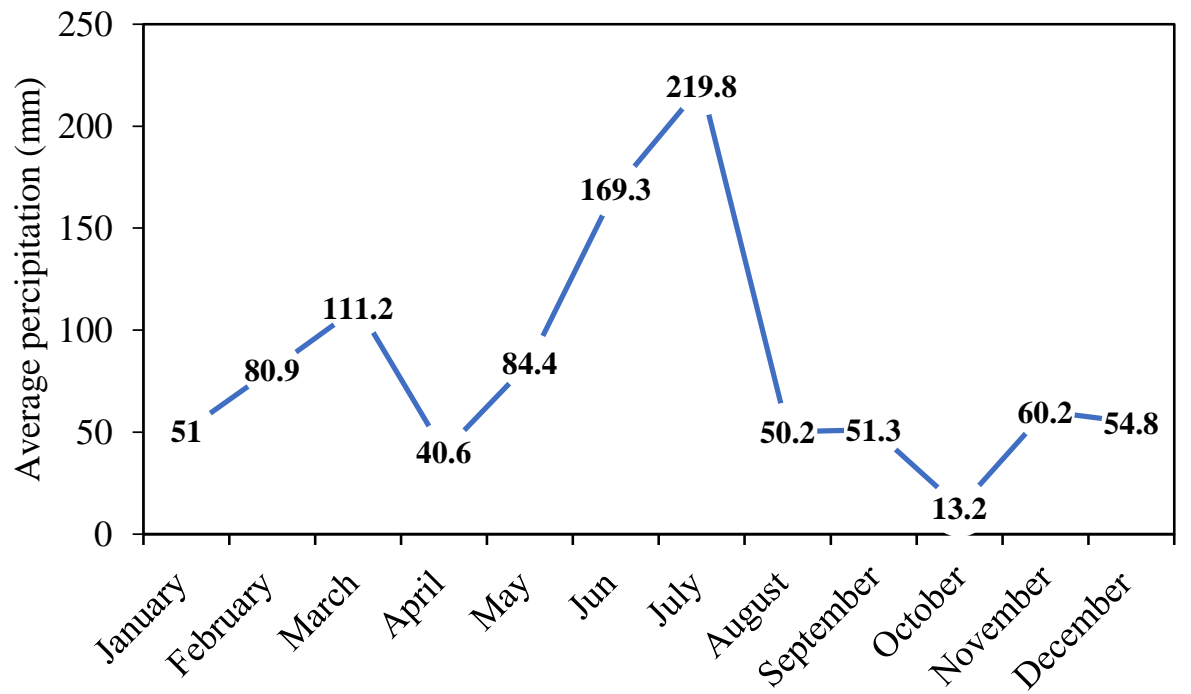

Figure 2. Average precipitation values shown by months during 2018. 


\section{Degree of lipid peroxidation - Malondialdehyde content}

The degree of lipid peroxidation was determined by spectrophotometric method according to HEATH and PACKER (1968), by measuring the concentration of reactive substances of thiobarbiturate acid (mainly malondialdehyde - MDA).

The leaves were homogenized in a mortar with liquid nitrogen until a fine powder appeared. Extraction was performed on $0.2 \mathrm{~g}$ of isolated plant material to which $0.1 \%$ trichloroacetic acid (TCA) solution was added, after which the contents were centrifuged at $10400 \mathrm{rpm}$ at $4{ }^{\circ} \mathrm{C}$ (Eppendorf Centrifuge $5415 \mathrm{R}$; Eppendorf, Hamburg, Germany). After extraction, supernatant was isolated and malondialdehyde reagent $(0.5 \%$ thiobarbiturate acid in $20 \%$ trichloroacetic acid) was added. The obtained supernatant was used for spectrophotometric readings at wavelengths of 532 and $600 \mathrm{~nm}$ (Metash uv/vis 5100B; Metash instrument Co., Ltd). A pure reagent for the determination of malondialdehyde was used as a blank. The concentration of lipid peroxidation products is presented as the amount of MDA per gram of fresh plant $(\mu \mathrm{mol} / \mathrm{g}$ of fw).

\section{Test weight}

The grain harvest in the experimental field was carried out in the phase of full maturity at the end of June and the beginning of July 2018. After harvest, yield and test weight were determined. Yield elements were determined on a plant sample collected from an area of 1 $\mathrm{m}^{2}$, with standard methods (KALUĐERSKI and FILIPOVIĆ, 1998).

\section{Statistical analysis of data}

Statistical analysis of the data was performed using the SPSS program (IBM SPSS Statistics, Version 20, Inc. 1989-2011, USA). The degree of lipid peroxidation (Fig. 3) was subjected to two-factor analysis of variance (ANOVA test) with cultivar and temperature as factors, after which the Fisher LSD test of multiple ranges with a significance level of $p \leq$ 0.05 was performed. The analysis of the correlation between MDA content and yield elements with a significance level of $p \leq 0.05$ was performed. A paired $T$ test with a significance level of $\mathrm{p} \leq 0.05$ was also performed.

\section{RESULTS AND DISCUSSION}

\section{Degree of lipid peroxidation - Malondialdehyde content}

In the analyzed cereal cultivars at conditions of moderate air temperature $\left(26^{\circ} \mathrm{C}\right)$, the MDA content ranged from $0.742 \mu \mathrm{mol} / \mathrm{g}$ to $1.242 \mu \mathrm{mol} / \mathrm{g}$ of fw (Fig. 3). The highest MDA content among the analyzed wheat cultivars under conditions of moderate temperature was found in the cultivar Ratarica $(1.242 \mu \mathrm{mol} / \mathrm{g}$ of $\mathrm{fw})$, while the lowest MDA content was found in the cultivar Mila $(0.742 \mu \mathrm{mol} / \mathrm{g}$ of $\mathrm{fw})$. In other cultivars, high MDA content at moderate air temperature conditions was found in cultivars Salasar $(1.152 \mu \mathrm{mol} / \mathrm{g} \mathrm{fw})$, Talas $(1.106$ $\mu \mathrm{mol} / \mathrm{g} \mathrm{fw})$, Hyfi $(1.097 \mu \mathrm{mol} / \mathrm{g} \mathrm{fw})$ and Vlajna $(1.023 \mu \mathrm{mol} / \mathrm{g} \mathrm{fw})$. The cultivar with a slightly lower MDA content at moderate air temperature conditions is cultivar Futura (0.965 $\mu \mathrm{mol} / \mathrm{g}$ fw). Cultivars in which a lower MDA content was observed under conditions of moderate air temperature are Renesansa, Apač and Carica. The mean value of MDA in moderate air temperature conditions was $0.999 \mu \mathrm{mol} / \mathrm{g} \mathrm{fw}$. 


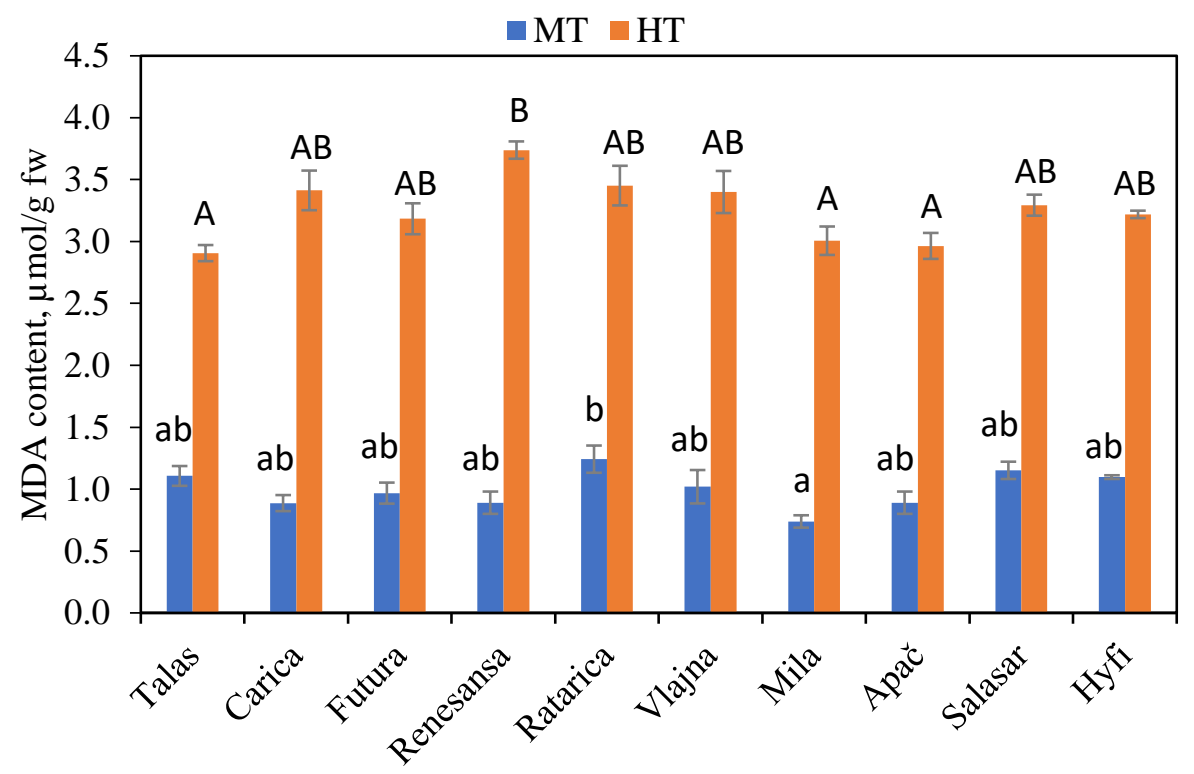

Figure 3. Mean values of MDA content in wheat cultivars in 2018 analyzed using two-factor analysis of variances - ANOVA, followed by Fisher's multi-range LSD test.

Values marked with different letters in moderate (MT, lower case) and high air temperature (HT, upper case) differ significantly $(p<0.05)$.

Under conditions of heat stress $\left(35.4{ }^{\circ} \mathrm{C}\right)$ among the analyzed wheat cultivars, the MDA content ranged from $2.908 \mu \mathrm{mol} / \mathrm{g}$ fw (cultivar Talas) to $3.735 \mu \mathrm{mol} / \mathrm{g}$ fw (cultivar Renesansa). Among other cultivars under conditions of heat stress, high MDA content was observed in cultivars Ratarica $(3.450 \mu \mathrm{mol} / \mathrm{g} \mathrm{fw})$, Carica $(3.414 \mu \mathrm{mol} / \mathrm{g} \mathrm{fw})$, Vlajna $(3.403$ $\mu \mathrm{mol} / \mathrm{g} \mathrm{fw})$, Salasar $(3.294 \mu \mathrm{mol} / \mathrm{g} \mathrm{fw})$ and Hyfi $(3.219 \mu \mathrm{mol} / \mathrm{g}$ fw $)$. Cultivars in which a slightly lower MDA content was found under heat stress were Futura $(3.181 \mu \mathrm{mol} / \mathrm{g} \mathrm{fw})$ and Mila $(3.013 \mu \mathrm{mol} / \mathrm{g} \mathrm{fw})$. The cultivar with the lowest MDA content under heat stress was Talas $(2.906 \mu \mathrm{mol} / \mathrm{g} \mathrm{fw})$. The mean value of MDA content under heat stress conditions was $3.258 \mu \mathrm{mol} / \mathrm{g} \mathrm{fw}$.

Using the paired t-test, it was shown that there is a highly significant statistical difference $(p<0.01)$ between the MDA content under moderate air temperature conditions compared to the MDA content under heat stress conditions (Tab. 1).

Table 1. Paired t-test of differences in MDA content in conditions of moderate (MT) and high air temperature (HT).

\begin{tabular}{|c|c|c|c|c|c|c|c|c|}
\hline \multicolumn{9}{|c|}{ Paired Differences - 95\% Confidence Interval of the Difference } \\
\hline & & Mean & $\begin{array}{l}\text { Std. } \\
\text { Dev. }\end{array}$ & $\begin{array}{l}\text { Std. } \\
\text { Err. }\end{array}$ & Lower & Upper & df & $\begin{array}{c}\text { Sig. } \\
\text { (2-tailed) }\end{array}$ \\
\hline Pair 1 & $\begin{array}{l}\text { MDA MT - } \\
\text { MDA HT }\end{array}$ & -2.259 & .332 & .074 & 2.4150 & -2.103 & 19 & .000 \\
\hline
\end{tabular}

MDA MT - MDA content in conditions of moderate air temperature; MDA HT - MDA content in conditions of high air temperature; Std. Dev. - standard deviation; Std. Err. - standard error; df degrees of freedom.

\section{Yield elements}

Based on the calculated values of yield and test weight during 2018, the mean value of yield elements was determined, which is shown in Table 2. In the analyzed wheat cultivars, the mean yields ranged from $2970 \mathrm{~kg} / \mathrm{ha}$ in the cultivar Renesansa to $4630 \mathrm{~kg} / \mathrm{ha}$ in the 
cultivar Mila. The cultivar that was characterized by the largest test weight during 2018 was the Mila cultivar $(76.0 \mathrm{~kg} / \mathrm{hL})$, while the Renaissance cultivar $(62.5 \mathrm{~kg} / \mathrm{hL})$ was characterized by the smallest test weight.

Table 2. Average values of yield elements of 10 wheat cultivars during 2018.

\begin{tabular}{lcc}
\hline Cultivar & Test weight $(\mathbf{k g} / \mathbf{h L})$ & Yield $(\mathbf{k g} / \mathbf{h a})$ \\
\hline Talas & $72.1 \pm 1.5$ & $3830 \pm 38.2$ \\
Carica & $73.0 \pm 1.5$ & $3580 \pm 42.5$ \\
Futura & $75.5 \pm 1.2$ & $3780 \pm 82.0$ \\
Renesansa & $62.5 \pm 1.3$ & $2870 \pm 43.5$ \\
Ratarica & $64.3 \pm 1.4$ & $3460 \pm 33.1$ \\
Vlajna & $75.4 \pm 1.1$ & $3731 \pm 59.1$ \\
Mila & $76.0 \pm 0.5$ & $4630 \pm 34.6$ \\
Apač & $73.3 \pm 1.1$ & $3730 \pm 55.1$ \\
Salasar & $70.1 \pm 1.5$ & $3350 \pm 102.3$ \\
Hyfi & $75.2 \pm 0.5$ & $3860 \pm 34.4$ \\
\hline
\end{tabular}

\section{Correlation of MDA content with yield elements}

For ten wheat cultivars, a correlation was made between the mean values of MDA content and yield and test weight. A significant $(p \leq 0.05)$ correlation was observed between MDA content under high air temperature conditions and yield (Fig. 4a). Pearson's correlation coefficient of $\mathrm{R}=-0.646$ indicates a significant correlation. In cultivars in which a high content of MDA was found in conditions of high air temperature, a lower yield was also observed. Cultivars in which a high content of MDA was found in conditions of high air temperature, a smaller amount of test weight was also determined (Fig. 4b). Pearson's correlation coefficient of $\mathrm{R}=-0.551$ indicates a significant correlation.

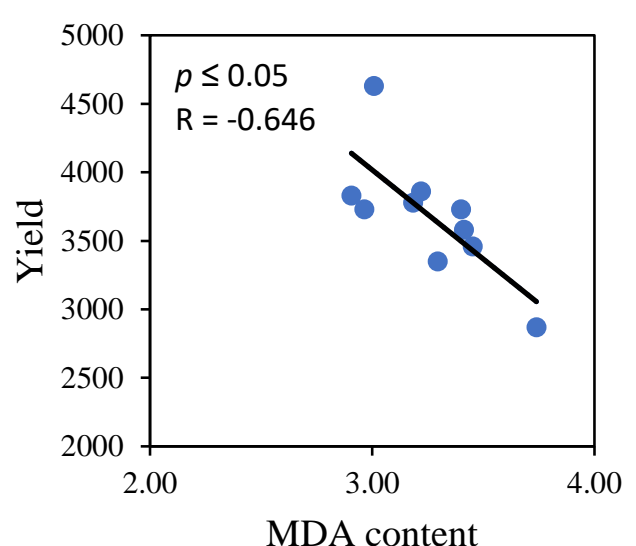

a)

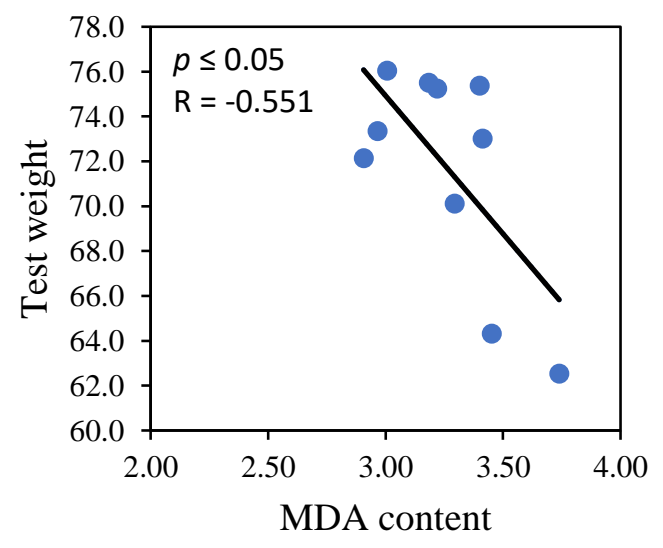

b)

Figure 4. Correlation between average values of MDA content and average values of yield (a) and test weight (b) in high air temperature conditions for 2018. For the given values, statistical analysis was performed in the SPSS program. Pearson's correlation coefficient $(\mathrm{R})$ was determined and significance was tested by $p$ - value.

Based on the obtained results, it was determined that the MDA content increased statistically significant in the examined cultivars under conditions of high air temperature compared to moderate air temperature. Significant difference in MDA content was found between the examined wheat cultivars. Significant difference in yield elements was also found between the examined wheat cultivars. The cultivar with the highest increase in MDA content in con- 
ditions of high air temperature is Renesansa $(2.848 \mu \mathrm{mol} / \mathrm{g} \mathrm{fw})$. This cultivar was characterrized by the lowest yield $(2870 \mathrm{~kg} / \mathrm{ha})$. The cultivar with the smallest increase in MDA content in conditions of high air temperature is the cultivar Talas $(1800 \mu \mathrm{mol} / \mathrm{g} \mathrm{fw})$. In the case of the Talas cultivar, the yield was significantly higher $(3830 \mathrm{~kg} / \mathrm{ha})$.

Research conducted by SAVICKA and SHKUTE (2010) has shown that long-term stress caused by high air temperature can lead to oxidative stress and growth inhibition in wheat cultivars. It was shown that abiotic stress, in addition to oxidative stress, also leads to numerous damages mediated by lipid peroxidation. Chlorophyll damage occurs (MISHRA and SINGHAL, 1992; DHYANI et al., 2013), the amount of total chlorophyll decreases (CHAKRABORTY and PRADHAN, 2012), damage to DNA molecule can occur (MARNETT, 1999) as well as damage to proteins (SALVAYRE et al., 2008). Under conditions of heat stress, among other things, it was shown that the nutrient reserves are depleted, which leads to plant starvation (HASANUZZMAN et al., 2013). It was shown that the effect of lipid peroxidation was most intense in wheat leaves (SAVICKA and SHKUTE, 2010). Considering that leaves are very important for wheat production (FRIEND, 1965), it is important to find cultivars more resistant to environmental stress conditions and to reduce the harmful effects of lipid peroxidation. Maintaining a high yield due to the harmful effects of abiotic factors is becoming an increasing challenge for modern agriculture (GILL and TUTEJA, 2010).

In this paper, it was shown that lipid peroxidation has a significant effect on yield reduction in the examined wheat cultivars. For that reason, it is important to find cultivars that are more resistant to the harmful effects of heat stress and thus enable higher productivity. The cultivars that were characterized in this study as more resistant to heat stress with a higher yield are Talas, Apač, Hyfi, Mila and Salasar.

These results suggest that wheat cultivars differ significantly in their ability to respond to heat stress, which could be useful for the development of heat tolerant wheat cultivars in breeding programs.

\section{Acknowledgment}

This work was supported by the Ministry of Education, Science and Technological Development of the Republic of Serbia (Agreement No. 451-03-68/2020-14/200122).

\section{References:}

[1] Alscher, R.G., Erturk, N., Heath, L.S. (2002): Role of superoxide dismutase's (SODs) in controlling oxidative stress in plants. Journal of Experimental Botany 53 (372): 1331-1341. doi: 10.1093/jexbot/53.372.1331

[2] AmirJani, M. (2012): Estimation of wheat responses to "high" heat stress. AmericanEurasian Journal of Sustainable Agriculture 6 (4): 222-233.

[3] Anderson, A.J., Sonali, P.R. (2004): Protein aggregation, Radical scavenging capacity, and stability of Hydrogen Peroxide Defense system in heat stressed Vinca and sweet pea leaves. Journal of the American Society for Horticultural Science 129 (1): 54-59. doi: 10.21273/JASHS.129.1.0054

[4] BarnabÁs, B., JÄGER, K., FEHÉR, A. (2008): The effect of drought and heat stress on reproductive processes in cereals. Plant, Cell \& Environment 31 (1): 11-38.

doi: 10.1111/j.1365-3040.2007.01727.x 
[5] Breusegem, F.V., VRanova, E., Dat, J.F., InZe, D. (2001): The role of active oxygen species in plant signal transduction. Plant Science 161 (3): 405-414.

doi: 10.1016/S0168-9452(01)00452-6

[6] Chakraborty, U., Pradhan, B. (2012): Oxidative stress in five wheat varieties (Triticum aestivum L.) exposed to water stress and study of their antioxidant enzyme defense system, water stress responsive metabolites and $\mathrm{H}_{2} \mathrm{O}_{2}$ accumulation. Brazilian Journal of Plant Physiology 24 (2): 117-130. doi: 10.1590/S1677-04202012000200005

[7] Ciais, P.H., Reichstein, M., Viovy, N., Granier, A., Ogée, J., Allard ,V., Aubinet, M., Buchmann, N., Bernhofer, C., Carrara, A., Chevallier, F., De Noblet, N., Friend, A.D., Friedlingstein, P., GrÜnwald, T., Heinesch, B., Keronen, P., Knohl, A., Krinner, G., Loustau, D., Manca, G., Matteucci, G., Miglietta, F., Ourcival, J.M., Papale, D., Pilegaard, K., Rambal, S., Seufert, G., Soussana, J.F., Sanz, M.J., Schulze, E.D., Vesala, T., Valentini, R. (2005): Europe-wide reduction in primary productivity caused by the heat and drought in 2003. Nature 437 (7058): 529533. doi: 10.1038/nature03972

[8] Dhyani, K., Ansari, M.W., Rao, Y.R., Verma, R.S., Shukla, A., Tuteja, N. (2013): Comparative physiological response of wheat genotypes under terminal heat stress. Plant Signaling \& Behavior 8 (6): e24564. doi: 10.4161/psb.24564

[9] DJukić, N., KnežEvić, D., Pantelić, D., ŽivanČević, D., TorbiCA, A., Marković, S. (2019): Expression of protein synthesis elongation factors in winter wheat and oat in response to heat stress. Journal of Plant Physiology 240: 153015.

doi: 10.1016/j.jplph.2019.153015

[10] Farooq, J., Khaliq, I., Ali, M.A., Kashif, M., Ali, Q., Rehman, A., Naveed, M., NAZEER, W., FAROOQ, A. (2011): Inheritance pattern of yield attributes in spring wheat at grain filling stage under different temperature regimes. Australian Journal of Crop Science 5 (13): 1745-1753.

[11] FRIEND, D.J.C. (1965): Tillering and leaf production in wheat as affected by temperature and light intensity. Canadian Journal of Botany 43 (9): 1063-1076. doi: 10.1139/b65123

[12] Fu, J., HuAnG, B. (2001): Involvement of antioxidants and lipid peroxidation in the adaptation of two cool-season grasses to localized drought stress. Environmental and Experimental Botany 45 (2): 105-114. doi: 10.1016/s0098-8472(00)00084-8

[13] GiLl, S.S., TUTEJA, N. (2010): Reactive oxygen species and antioxidant machinery in abiotic stress tolerance in crop plants. Plant Physiology and Biochemistry 48 (12): 909930. doi: 10.1016/j.plaphy.2010.08.016

[14] Griffin, J.J., Ranney, T.G., Pharr, D.M. (2004): Heat and drought influence photosynthesis and water relations, and soluble carbohydrates of two ecotypes of redbud (Cercis canadensis). Journal of American Society for Horticultural Science 129: 497-502. doi: 10.21273/JASHS.129.4.0497

[15] GuY, C. (1999): The influence of temperature extremes on gene expression, genomic structure, and the evolution of induced tolerance in plants. In: Lerner, H.R. (ed.) Plant Responses to Environmental Stresses. Marcel Dekker, New York, USA pp. 497-548. 
[16] HeAth, R.L., PACKER, L. (1968): Photoperoxidation in isolated chloroplasts. I. Kinetics and stoichiometry of fatty acid peroxidation. Archives in Biochemistry and Biophysics 125 (1): 189-198. doi: 10.1016/0003-9861(68)90654-1

[17] Hasanuzzman, M., Nahar, K., Mahabub Alam, M., Roychowdhury, R., Fujita, M. (2013): Physiological, Biochemical and Molecular Mechanisms of Heat Stress Tolerance in Plants. International Journal of Molecular Sciences 14 (5): 9643-9684. doi: 10.3390/ijms14059643

[18] KALUĐERSKI, G., FiliPOVIĆ, N. (1998): Metode ispitivanja kvaliteta žita, brašna i gotovih proizvoda. Zavod za tehnologiju žita i brašna, Novi Sad.

[19] Karuppanapandian, T., Jun-Cheol, M., Changsoo, K., Kumariah, M., Wook, K. (2011): Reactive oxygen species in plants: their generation, signal transduction and scavenging mechanisms. Australian Journal of Crop Science 5 (6): 709-725.

[20] Kavi Kishor, P. B., Sangam, S., Amrutha, R.N., Sri Laxmi, P., Naidu, K.R., RaO, K.R.S.S., RAO, S., REDDY, K.J., TheriAPPAN, P., SREENIVASUlU, N. (2005): Regulation of proline biosynthesis, degradation, uptake and transport in higher plants: Its implications in plant growth and abiotic stress tolerance. Current Science 88 (3): 424-438.

[21] Khamssi, N.N., GoleZANI, K.G., NAJAPHY, A., ZEHTAB, S. (2011): Evaluation of grain filling rate, effective grain filling period and resistance indices under acclimation to gradual water deficit stress in chickpea cultivars. Australian Journal of Crop Science 5 (6): 1044-1049.

[22] Kumar, R.R., Goswami, S., Sharma, S.K., Singh, K., Gadpayle, K.A., Kuma, N., RAI, G.K., SINGH, M., RAI, R.D. (2012): Protection against heat stress in wheat involves change in cell membrane stability, antioxidant enzymes, osmolyte, $\mathrm{H}_{2} \mathrm{O}_{2}$ and transcript of heat shock protein. International Journal of Plant Physiology and Biochemistry 4 (4): 83-91. doi: 10.5897/IJPPB12.008

[23] Liu, X., Huang, B. (2000): Heat Stress Injury in Relation to Membrane Lipid Peroxidation in Creeping Bentgrass. Crop Science 40 (2): 503-510.

doi: $10.2135 /$ cropsci2000.402503x

[24] Mahla, R., Madam, S., Munjal, R., BeHL, R.K. (2012): Heat-induced oxidative stress and changes in protein profile in wheat cultivars. Quality assurance and safety of crops and foods 4: 137. doi: 10.1111/j.1757-837X.2012.00141.X

[25] MARCUM, K.B. (1998): Cell membrane thermostability and whole-plant heat tolerance of Kentucky bluegrass. Crop Science 38 (5): 1214-1218.

doi: 10.2135/cropsci1998.0011183X003800050017x

[26] MARnetT, L.J. (1999): Lipid peroxidation-DNA damage by malondialdehyde. Mutation Research/Fundamental and Molecular Mechanisms of Mutagenesis 424 (1-2): 83-95. doi: 10.1016/S0027-5107(99)00010-X

[27] Mishra, R.K., Singhal, G.S. (1992): Function of Photosynthetic Apparatus of Intact Wheat Leaves under High Light and Heat Stress and Its Relationship with Peroxidation of Thylakoid Lipids. Plant Physiology 98 (1): 1-6. doi: 10.1104/pp.98.1.1

[28] Mustafa, H.F.W, Batool, N., Ali, Q., FarooQ, J., Ilyas, N., Mahmood, T., Ali, G.M., SHEHZAD, A. (2013): Comprehensive overview for developing drought tolerant transgenic wheat (Triticum aestivum L.). Journal of agrobiology 30 (2): 55-69. doi: 10.2478/agro-2013-0006 
[29] Porter, J.R, Gawith, M. (1999): Temperatures and the growth and development of wheat: a review. European Journal of Agronomy 10: 23-36. doi: 10.1016/S1161-0301(98)00047-1

[30] SavickA, M., ShKUTE, N. (2010): Effects of high temperature on malondialdehyde content, superoxide production and growth changes in wheat seedlings (Triticum aestivum L.). Ekologija 56 (1): 26-33. doi: 10.2478/v10055-010-0004-x

[31] Suzuki, N., MitTler, R. (2006): Reactive oxygen species and temperature stresses: A delicate balance between signaling and destruction. Physiologia Plantarum 126 (1): 4551. doi: 10.1111/j.0031-9317.2005.00582.x

[32] Taulavuori, E., Hellström, E-K., Taulavuori, K., Laine, K. (2001): Comparison of two methods used to analyze lipid peroxidation from Vaccinium myrtillus (L.) during snow removal, reclamation and cold acclimation. Journal of Experimental Botany 52 (365): 2375-2380. doi: 10.1093/jexbot/52.365.2375

[33] Vacca, R.A., de Pinto, M.C., Valenti, D., Passarella, S., Marra, E., De Gara, L. (2004): Production of reactive oxygen species, alteration of cytosolic ascorbate peroxidase, and impairment of mitochondrial metabolism are early events in heat shock induced programmed cell death in tobacco Bright Yellow 2 cells. Plant Physiology 134 (3): 1100-1112. doi: 10.1104/pp.103.035956 